\title{
Retention, Progression and the Taking of Online Courses
}

\author{
Scott James \\ Predictive Analytics Reporting Framework \\ Karen Swan \\ University of Illinois Springfield \\ Cassandra Daston \\ Predictive Analytics Reporting Framework
}

\begin{abstract}
Online learning continues to grow at post-secondary institutions across the United States, but many question its efficacy, especially for students most at-risk for failure. This paper engages that issue. It examines recent research on the success of community college students who take online classes and explores similar comparisons using 656,258 student records collected through the Predictive Analytics Reporting (PAR) Framework. In particular, the research investigated retention rates for students in three delivery mode groups - students taking only onground courses, students taking only online courses, and students taking some courses onground and some courses online at five primarily onground community colleges, five primarily onground four-year universities, and four primarily online institutions.

Results revealed that taking some online courses did not result in lower retention rates for students enrolled in primarily onground community colleges participating in the PAR Framework. Moreover, although retention rates were lower for such students taking only online courses than for similar students taking only onground or blending their courses, much of the difference could be explained by extraneous factors. Essentially no differences in retention between delivery mode groups were found for students enrolled in primarily onground four-year universities participating in the PAR Framework, while at participating primarily online institutions, students blending their courses had slightly better odds of being retained than students taking exclusively onground or exclusively online courses. No differences between the latter groups were found at these institutions.

Patterns of retention were similar regardless of gender across institutional categories, and were mostly similar regardless of Pell grant status with the exception of fully online students at traditional community colleges. Age, however, did differentially affect delivery mode effects. Older students taking only online courses were retained at higher rates than younger students taking only online courses at both primarily onground community colleges and primarily online institutions. The results suggest that, despite media reports to the contrary, taking online courses is not necessarily harmful to students' chances of being retained, and may provide course-taking opportunities that otherwise might not be available, especially for nontraditional students.
\end{abstract}




\section{Introduction}

Online learning continues to grow at post-secondary institutions across the United States, but many question its efficacy, especially for students most at-risk for failure. This paper engages that issue. It examines recent research on the success of community college students who take online classes and explores similar comparisons using 656,258 student records collected through the Predictive Analytics Reporting (PAR) Framework. In particular, it investigates retention rates for students in three delivery mode groups - students taking only onground courses, students taking only online courses, and students taking some courses onground and some courses online at five primarily onground community colleges, five primarily onground four-year universities, and four primarily online institutions. It also explores potentially differential effects of delivery mode related to Pell grant status, gender, and/or age.

In the sections which follow, relevant research on the effects of online learning on the success of community college students is summarized, and the PAR Framework is explained. The Methodology section identifies the research questions addressed, the data sources used, and the methods of analyses. In the Results section, findings are given for primarily onground community colleges, primarily onground four-year universities, and primarily online institutions broken out by research questions. The Discussion section explores the implications of some of the findings, examines results across institutions, and notes the limitations of the research.

Finally, the major findings of the study are reiterated in the Conclusions.

\section{Background}

Online learning is no longer an anomaly in American higher education. According to national data, in the fall 2013 semester over 5.2 million, or $25 \%$ of all higher education students in the United States took at least one online course (Allen \& Seaman, 2015) and indications are that online learning will continue to grow in the near future.

In addition, most researchers agree that learning outcomes from online courses are not significantly different from traditional courses (Bernard et al., 2009; Means, Toyama, Murphy, Bakia, \& Jones, 2009). However, as educators have come to accept the similarity of learning regardless of delivery mode, they have also come to believe that retention and progression are greater problems online (Allen \& Seaman, 2015; Moore \& Fetzner, 2009). Indeed, there have been several, relatively recent, large-scale studies comparing retention and progression for community college students taking online and traditional classes that support such a view.

Two such studies were undertaken by the Community College Research Center (CCRC) at Teachers College, Columbia University involving cohorts in the Virginia (Jaggers \& Xu, 2010) and Washington state (Xu \& Jaggers, 2011) community college systems. The 2004 cohorts in both systems were followed for five years. Because the researchers found that better prepared students were more likely to enroll in online courses, they limited their comparisons to the population of students who ever took an online course. They found that in both systems, "ever online" students were more likely to fail or withdraw from online courses than from face-to-face courses (Xu \& Jaggers, 2011). In addition, the researchers found that students who took online coursework in early terms were slightly but significantly less likely to return to school in subsequent terms, and students who took a higher proportion of credits online were slightly but significantly less likely to graduate, attain a certificate, or transfer to a four-year institution (Jaggers \& Xu, 2010; Xu \& Jaggers, 2011).

In a similar, more recent, study of student performance in the cohort enrolling in the California Community College system in the 2008/09 academic year, Hart, Friedman, and Hill (2015) found that students' likelihood of completing and/or passing courses (receiving a $\mathrm{C}$ or better) were lower for online courses than they were for those offered in face-to-face formats. Controlling for possible differences in courses, students, and instructors, the researchers found students were 6.8 to 
8.9 percentage points less likely to complete, and 10.9 to 15.2 percentage points less likely to pass online courses.

Shea and Bidjerano (2014), however, reported seemingly different findings using somewhat different outcome measures. Using data from the Beginning Post-secondary Survey (BPS), they compared the degree and/or certificate completion rates of community college students who took one or more courses online with those of students who did not take any online courses. The BPS data comes from a sample of students who initially enrolled in a US post- secondary degree program in 2004. These same students were surveyed again in 2006 and 2009. Shea and Bidjerano explored the data in an attempt to replicate and extend the CCRC findings. They found, however, that controlling for relevant background characteristics, students who took some of their early courses online had a significantly better chance of attaining a community college credential than those who only took faceto-face courses.

Some explanation for these seemingly disparate results can be found in another study of California community colleges. Johnson and Cuellar Majia (2014) studied an earlier cohort who initially enrolled in California community colleges in the fall of 2006. Modeling their work on Xu \& Jaggers, the researchers found that students taking online classes were less likely to complete them, and less likely to complete them with a passing grade, than students in enrolled in face-to-face classes. However, when they examined long-term outcomes, Johnson and Cuellar Majia found that students who took at least some online courses were more likely to earn an associate's degree or transfer to a four-year institution than those who didn't.

The research reported in this paper builds on the above studies and investigates the seeming anomalies among them. In particular, it compares both course completion and retention among students enrolled in solely online, solely onground, or both online and onground courses (ever online) across five quite dissimilar primarily onground community colleges. In addition, it tests to see whether or not similar patterns can be found among female vs. male community college students, older vs. younger community college students and/or among community college students receiving or not receiving Pell grants. Moreover, the research also investigates course completion and retention among students enrolled in five quite different four-year colleges and among students enrolled in four very different primarily online institutions. To do so, it uses data collected through the Predictive Analytics Reporting (PAR) Framework.

\section{Predictive Analytics Reporting (PAR) Framework}

The PAR Framework is a non-profit, multi-institutional collaborative that provides member institutions with tools and resources for identifying risks and improving student success. PAR member institutions provide anonymized student-level data for all credential-seeking students who began taking courses at the institution in August 2009 or later. At the time of this writing, the PAR data set has more than 2 million student records and 20 million course records from more than 30 institutions and includes data through Fall 2014 for most institutions and through Spring 2015 for some.

These data include

- student demographic information, such as age, gender, race/ethnicity, military and veteran status, permanent residence zip code, Pell eligibility

- prior academic information, including high school GPA, transfer GPA, prior amount and type of college credits earned

- student course information for all courses taken, including specific course titles, course length, course size, outcomes, and delivery mode

- other student academic information, such as majors pursued, specific credentials sought, 
transfer credits brought in after enrollment, and credentials earned.

PAR member institutions comprise a range of the many diverse options for postsecondary education, including traditional open admission community colleges, 4-year traditional selective admission public institutions, and nontraditional primarily online institutions, both for-profit and nonprofit.

A key feature of the PAR dataset is the use of PAR's openly published common data definitions by all member institutions. Because all data provided by PAR member institutions utilize these common definitions, cross-institutional "apples to apples" analyses on the combined data set can be performedto better understand the factors that impact student success generally as well as locally.

In addition, having relatively comprehensive, detailed data for all credential-seeking students, rather than a sample from each institution, enables a more accurate understanding of the student and institutional-level factors that impact risk and success. It also makes it possible to more effectively control for confounding variables that might be contributing to observed differences between student groups.

\section{Methodology}

The study reported here investigated the effects of delivery mode on the retention and progression of undergraduate students. It explored differences in retention and progression among students who took all their classes online, students who took all their classes onground, and students who blended online and onground classes. The research questions addressed included:

- Do community college students who enroll in online courses have poorer course completion rates and are they retained at lower rates than community college students who take all their courses onground?

- Does delivery mode differentially affect particular groups of community college students?

- Do students enrolled in four-year colleges who take online courses have poorer course completion rates and are they retained at lower rates than four-year college students who take all their courses onground?

- Does delivery mode differentially affect particular groups of four-year college students?

- Are there any differences in course completion and/or retention rates associated with differing delivery modes at primarily online institutions?

- Does delivery mode differentially affect particular groups of students attending primarily online institutions?

\section{Data Sources}

In the current study, the impact of course delivery mode on student outcomes in various types of post-secondary settings was explored. Fourteen PAR member institutions were included in the study:

- 5 primarily onground community colleges (213,056 student records)

- 5 primarily onground 4-year universities (113, 036 student records)

- 4 primarily online institutions (330,166 student records)

Data sources were all student- and course-level records for students who began their studies between September 2009 and December 2012 at these schools. Thus, all students included in the 
analyses had the opportunity for at least 18 months of enrollment in order to determine retention.

Students at each institution were grouped according to delivery mode-fully on- onground, fully online, or a blend of onground and online-based on the courses they enrolled in up to and immediately following the first six months of their enrollment at the institution. Students were considered fully onground if they only took onground courses during that period; they were considered fully online if they only took online courses during that period, and they were considered blended if they took any combination of onground and online courses during that period.

Because post-secondary institutions have course enrollment periods of differing lengths (e.g., semesters, quarters, continuous short- or long-course enrollment periods), the following approach was used to determine a student's course-taking behavior, credits attempted, and credit ratio in their first few months at the institution. For each student included in the study, all courses taken during the student's first six months' enrollment, plus the next course or courses completed after the six-month date, were used to determine delivery mode, credit ratio, and credits attempted. If more than one course ended on the same end date, all were included. If the student stopped taking courses prior to the six-month point, those courses were included. Thus, for all institutions in the study, delivery mode, credit ratio and credits attempted were based on approximately eight to nine months of course data. For traditional semester schools, one academic year was typically included; for quarter schools, three quarters; for continuous enrollment school, eight to nine months of course-taking. Variables regarding credits (including delivery mode, credits attempted, and credit ratio) were measured in aggregate for this initial period.

The primary outcome of interest in this study was retention to the second year; a student was considered retained if they were enrolled in any course at the institution 12 to 18 months after their first course start date, or if they had earned a credential or graduated at any time between their first course start date and 18 months later. Progression during a student's first eight to nine months was measured by credit ratio which was operationalized as the number of credits earned with a grade of $\mathrm{C}$ or better divided by the number of credits attempted during the time period. Credits attempted during this time period were also recorded for each student.

Additional variables that could account for differences in retention or progression, such as student demographic and other academic factors, were explored and used as control variables providing greater confidence that the results concerning retention were related to delivery mode rather than other variables.

\section{Methods of Analyses}

Exploratory analysis was conducted comparing retention rates for three different groups of students based on their course-taking behaviors (delivery modes) in the first (approximately) eight to nine months at the institution. The initial exploratory analyses also compared differences in retention among the three delivery modes by Pell recipients, student age at entry, and gender.

Credit ratios and credits attempted for students taking only onground, only online, or blending their courses were additionally recorded and descriptively compared.

Because this was not a controlled experiment, there was concern that differences in retention rates among students in the different delivery mode groups could be due to inherent differences among those students, rather than an effect of their chosen delivery mode. To address this issue, variables that did not directly measure student success but had significant associations with retention at each institution were controlled for in a logistic regression model. Such variables affecting retention were identified at each institution individually and controlled for.

The effect of delivery mode was then added to the model to estimate the true relationship between course delivery mode and student retention. Variables that directly measure academic performance, 
such as credit completion, were not included as controls since there was no way of determining whether or not higher credit completion was a result of delivery mode or if the delivery mode chosen by a student was a result of the student being more academically gifted or motivated. However, course load (credits attempted), rather than course completion was controlled for in this study.

The following variables were considered as potential confounding factors:

- Military status at entry

- Pell status

- GED status

- Gender

- Race

- Degree sought at entry

- Student type at entry (as indicated by institution)

- Transfer college type

- Veteran at entry

- Credits attempted

- Developmental education ratio

- Student age at entry

- Median income associated with a student's home zip code

- High School GPA

Any of the above factors found to be significantly associated with retention at each individual institution were included as control variables in that institution's model. Two-way interactions between the above factors were also considered when their inclusion improved overall model fit. After appropriate control variables had been determined, the effect of delivery mode was added and measured as an odds ratio.

After calculating the average 12-18-month retention rates, average credit ratios, and credits attempted for students in each delivery group (blended, fully onground, and fully online) at each institution, averages for these three variables were aggregated across institutions in three categories: primarily onground community colleges, primarily onground four-year universities, and primarily online institutions. In each grouping of institutions, the averages for retention rates, credit ratio, and credits attempted give equal weight to each institution in the group, regardless of enrollment; that is, aggregated data was averaged with institution as the unit of analysis in an attempt to fairly account for the diversity represented by them.

\section{Results}

In the sections which follow results are given for each set of institutions-primarily onground community colleges, primarily ongound four-year universities, and primarily online institutions-relative to the research questions posed.

\section{Primarily Onground Community Colleges}

In this section, results are presented for students enrolled in five primarily onground community colleges and research questions related to them are explored. The community colleges in this group were public institutions located throughout the United States - in Florida, Ohio, Texas, Washington state, and Hawaii-and ranged in number of students enrolled for the period studied from almost 23,000 to just over 93,000. They also differed in the percentages of students who had Pell grants (41\% 
to $63 \%)$. Females outnumbered males at all the primarily onground community colleges studied. Traditionally aged students ( $<26$ years old) accounted for nearly three times as many community college students as older students

Do community college students who enroll in online courses have poorer course completion rates and are they retained at lower rates than community college students who take all their courses onground?

Table 1 shows the average retention percentages, credit ratios, and credits attempted for students enrolled in the five PAR community colleges considered in the analysis.

Table 1:Average retention, credit ratios, and credits attempted for community college students by delivery mode

\begin{tabular}{|r|c|c|c|c|}
\hline & $\mathrm{N}$ & $\begin{array}{c}12-18 \\
\text { months }\end{array}$ & credit ratio & $\begin{array}{c}\text { credits } \\
\text { attempted }\end{array}$ \\
\hline blended & 91,622 & $58 \%$ & 0.67 & 19.2 \\
\hline fully onground & 112,269 & $51 \%$ & 0.64 & 16.8 \\
\hline fully online & 9,165 & $30 \%$ & 0.64 & 10.2 \\
\hline
\end{tabular}

The data show that across institutions, community college students taking some of their courses online and some onground had a retention rate of $58 \%$, students taking all of their course onground had a retention rate of $51 \%$, while only $30 \%$ of community college students taking all of their courses online were retained in the year following their first enrollment.

After controlling for possible confounding variables, logistic regression found that both the blended group and the fully onground group were slightly more likely to be retained than students who were fully online at all but one PAR community college. Odds ratios indicated that students blending their courses had 1.2 to 1.6 times greater odds of being retained than fully online students, and that fully onground students had 1.3 to 1.6 times greater odds of being retained than fully online students (Table 2).

There were no statistical differences between students in the blended group and fully onground students for four of the five institutions, indicating that observed differences in retention can be explained by the control variables rather than differences in delivery mode. For the one institution that did show a significant difference in odds between the blended group and the fully onground group, fully onground students had just 1.1 times the odds of being retained. The odds ratios for each institution are listed in the chart below. The retention odds of the delivery group listed first in the pairs were used as the numerators for the odds ratios.

Table 2: Odds ratios comparing the odds of retention to a second year of students in differing delivery mode groups

\begin{tabular}{|r|c|c|c|c|c|}
\hline & Institution & Institution & Institution & Institution & Institution \\
& 1 & 2 & 3 & 4 & 5 \\
\hline fully onground vs. blended & 1.0 & 1.0 & 1.0 & 1.1 & 1.0 \\
\hline blended vs. fully online & 1.5 & 1.6 & 1.5 & 1.2 & 1.0 \\
\hline fully onground vs. fully online & 1.6 & 1.5 & 1.6 & 1.3 & 1.0 \\
\hline
\end{tabular}

The results reveal that students blending their courses attempted more credits on average (19.2) than either students taking solely onground (16.8) or solely online (10.2) courses.

Interestingly, there was very little difference in the average credit ratios (credits of $\mathrm{C}$ or better/credits attempted) among groups. 
The results suggest that while taking all courses online had a mild negative impact on PAR community college students' retention, taking some online courses (blended) did not.

These results are distinctly different from the CCRC results (Jaggers \& Xu, 2010; Xu \& Jaggers, 2011) which suggested that taking any online courses hurt community college students' retention and progression. It may be that separating students taking only online courses from those taking some online courses (as done in this study) is what made the difference. The retention rates for community college students taking only online courses in the current study are quite low. It is also important to note, however, that less than $5 \%$ of community college students at the PAR institutions studied took all their courses online.

Moreover, credit ratios (which in some sense quantify pass rates) are remarkably similar across delivery modes in this study, indicating that community college students taking some or all of their courses online were as likely to complete and pass their courses as students taking all of their courses onground. Indeed, students blending online and onground courses were slightly more likely to complete their courses with passing grades than either students taking all their courses onground or students taking their courses only online. These findings seemingly contradict not only those of the CCRC (Jaggers \& Xu, 2010; Xu \& Jaggers, 2011), but those from the California community colleges (Hart, Friedman, \& Hall, 2015; Johns \& Cuellar Majia, 2014). The differences may be definitional. The credit ratio used in this research is just that: a ratio; it needs to be multiplied by credits attempted to get the number of courses completed with a passing grade. As the fully online students in the community college population studied in this research attempted far fewer credits, they would have obtained far fewer as well. Thus the small number of fully online students could bring down the "ever online" averages if one did not separate students who take all online courses from students who take some online courses, as was done in this study. In any case, the results clearly deserve further investigation.

\section{Does delivery mode differentially affect particular groups of community college students?}

To test whether delivery mode particularly affected different sorts of students, average 12-18month retention rates were aggregated by delivery modes for students receiving or not receiving Pell grants, for female and male students, and for student age at entry (under age 26 or 26 years and older) across PAR primarily onground community colleges.

Table 3: Community college student retention by Pell status

\begin{tabular}{|r|cc|cc|}
\hline & \multicolumn{2}{|c|}{ NO PELL } & \multicolumn{2}{c|}{ PELL } \\
\hline & $\mathrm{N}$ & 12-18 mo. retention & $\mathrm{N}$ & $12-18$ mo. retention \\
\hline blended & 47,117 & $53 \%$ & 37,211 & $62 \%$ \\
\hline fully onground & 54,758 & $47 \%$ & 39,843 & $57 \%$ \\
\hline fully online & 5,674 & $22 \%$ & 3,426 & $42 \%$ \\
\hline
\end{tabular}

Table 3 shows the average retention percentages by Pell status for PAR students enrolled in community colleges. The data shows that students with Pell grants were retained at higher rates than those who did not have them, which may indicate the importance of financial support for such students. Moreover, the overall patterns of retention percentages within delivery mode groupings were somewhat different for students receiving and those not receiving Pell grants.

The difference between students taking only onground classes and those taking only online classes was considerably less for students with Pell grants than it was for students without Pell grants. The difference between students taking only onground classes and students taking some onground and some online classes, however, was essentially the same. 
Table 4: Community college student retention by gender

\begin{tabular}{|r|cc|cc|}
\hline & \multicolumn{2}{|c|}{ FEMALE } & \multicolumn{2}{c|}{ MALE } \\
\hline & $\mathrm{N}$ & 12-18 mo. retention & $\mathrm{N}$ & 12-18 mo. retention \\
\hline blended & 54,179 & $60 \%$ & 37,810 & $56 \%$ \\
\hline fully onground & 57,439 & $55 \%$ & 54,488 & $49 \%$ \\
\hline fully online & 6,167 & $34 \%$ & 2,987 & $25 \%$ \\
\hline
\end{tabular}

Table 4 shows the average retention rates for female and male students enrolled in PAR community colleges. They show that more women were enrolled and that they were retained at slightly higher rates than men. It is also interesting to note that women were considerably more likely than men to take any online classes. Just over half (51\%) of the community college women in this study took at least one online course as compared with only $43 \%$ of the men, perhaps because more men are enrolled in technical classes only offered onground. The patterns of retention by delivery mode, however, were similar, indicating that delivery mode effects were not affected by gender.

Table 5: Community college student retention by age

\begin{tabular}{|r|c|c|c|c|}
\hline & \multicolumn{2}{|c|}{ YOUNGER (<26 years) } & \multicolumn{2}{c|}{ OLDER (26+ years) } \\
\hline & $\mathrm{N}$ & $12-18$ mo. retention & $\mathrm{N}$ & $12-18$ mo. retention \\
\hline blended & 66,239 & $58 \%$ & 25,383 & $57 \%$ \\
\hline fully onground & 86,512 & $53 \%$ & 25,757 & $47 \%$ \\
\hline fully online & 4,819 & $26 \%$ & 4,346 & $33 \%$ \\
\hline
\end{tabular}

Table 5 compares retention for each of the delivery modes between students 25 years of age and younger and students older than 25. A greater percentage of older community college students took only online courses, perhaps indicating their greater need for them, and older students taking only online courses were retained at much higher rates than younger students taking only online courses. In contrast, a greater percentage of younger community college students took only onground courses, and they were retained at much higher rates than older students taking only onground courses.

The results of these comparisons, then, suggest that while delivery mode did not differentially affect students grouped by gender, students grouped by Pell status were somewhat affected. Younger vs. older community college students were clearly differentially affected by delivery mode. The data suggest that taking only online classes is more harmful to younger students, and those without Pell grants in terms of observed retention rates. Potential differential effects of taking classes online should be explored for other student populations, especially at- risk groups such as ethnic and racial minorities, or students who are the first in their families to attend college.

\section{Primarily Onground Four-Year Colleges}

In this section, results for students enrolled in five, primarily onground, four-year colleges are presented and research questions related to them investigated. The analyses were initiated to see whether results for students taking online courses at community colleges also apply to students taking online courses at four-year universities.

The institutions represented in these analyses are public universities located throughout the United States - in Florida, Illinois, North Dakota, Arizona, and Hawaii-and ranged in number of 
students enrolled for the period studied from just over 3,000 to almost 60,000. Fewer students had Pell grants at these institutions than at the community colleges studied (18\% to $42 \%)$ and females outnumbered males at all but one of the primarily onground four-year colleges studied. There were also slightly more traditionally aged students enrolled in the four-year universities studied.

Do students enrolled in four-year colleges who take online courses have poorer course completion rates and are they retained at lower rates than four-year college students who take all their courses onground?

Table 6 shows the average retention rates, credit ratios, credits attempted for PAR students enrolled in four-year colleges offering primarily onground programs. There were fewer university students than community college students in the PAR database, and there were slightly more students in this population blending their classes than students taking only onground classes. Students taking only online classes accounted for only a small percentage (6.5\%) of these students, but it is interesting to note that combining students blending their classes with students taking only online classes reveals that the majority of students in this population were taking at least some online classes (ever online), which was not the case among the primarily onground community college population.

Table 6: Retention rates, credit ratios, \& credits attempted for primarily onground 4-year college students by delivery mode

\begin{tabular}{|r|c|c|c|c|}
\hline & $\mathrm{N}$ & $\begin{array}{c}12-18 \text { mo. } \\
\text { retention }\end{array}$ & credit ratio & $\begin{array}{c}\text { credits } \\
\text { attempted }\end{array}$ \\
\hline blended & 54,867 & $79 \%$ & 0.80 & 24.4 \\
\hline fully onground & 53,544 & $76 \%$ & 0.81 & 25.2 \\
\hline fully online & 7,625 & $60 \%$ & 0.74 & 14.5 \\
\hline
\end{tabular}

The data in Table 6 also show that students at primarily onground four-year universities were retained at higher percentages than primarily onground community college students in the PAR database. Moreover, although differences in retention percentages between delivery mode groupings were not as pronounced for the university population, the ranking patterns were the same. Students taking some of their courses online and some onground had a retention rate of $79 \%$, students taking all of their course onground had a retention rate of $76 \%$, and students taking all of their courses online had a retention rate of $60 \%$.

After controlling for possible confounding variables in a logistic regression model, results showed that in the majority of cases no group was at higher risk than any other of not being retained at twelve to eighteen months. In one instance, students in the blended and fully onground groups had greater odds of being retained than fully online students with odds ratios of 1.6 and 1.8 respectfully. Significant differences were observed between students taking a blend of courses and students taking all of their courses onground at two institutions, but the effects were split: at one institution the fully onground group had only .77 times the odds of being retained as the blended group, while the fully onground group had 1.1 times greater odds of being retained at the other institution. Overall, the results suggest that the extraneous factors controlled for at each institution accounted for most or all of the differences in retention, rather than the effect of delivery mode. There was little evidence that taking any courses online at a primarily onground four-year university placed a student at greater risk of not being retained, once other variables are accounted for.

Odds ratios resulting from modeling the effect of delivery mode on retention with additional variables controlled for are shown in Table 7. 
Table 7: Odds ratios comparing the odds of retention to a second year of students in differing delivery mode groups

\begin{tabular}{|r|c|c|c|c|c|}
\hline & Institution & Institution & Institution & Institution & Institution \\
& 1 & 2 & 3 & 4 & 5 \\
\hline fully onground vs blended & .77 & 1.0 & 1.0 & 1.1 & 1.0 \\
\hline blended vs fully online & na* & 1.0 & 1.0 & 1.6 & 1.0 \\
\hline fully onground vs fully online & $\mathrm{na}^{*}$ & 1.0 & 1.0 & 1.8 & 1.0 \\
\hline
\end{tabular}

*not enough fully online students at Institution 1 for valid comparison

Credit ratios were higher for students at four-year universities in this study than for students at community colleges, and although the average credit ratios for students blending their courses and students taking all their courses onground were remarkably similar (.80 and .81 respectively), the average credit ratio for students taking only online courses was considerably smaller (.74). Similarly, the number of credits attempted by students taking only onground and students taking onground and online courses were similar (25.2 and 24.4 respectively) but students taking only online courses at primarily onground four-year universities attempted far fewer credits (14.5). It is possible that students taking only online courses chose to do so because they had busier lives than students taking some or all of their courses onground. Perhaps these students attempted fewer courses and had a more difficult time passing them for the same reason. The finding clearly deserves further investigation.

\section{Does delivery mode differentially affect particular groups of four-year university students?}

As with the community college data, further analyses were made to see whether Pell status, gender or age differentially affected four-year students in the PAR database. Indications were that they did not.

Table 8: Four-year college student retention by Pell status

\begin{tabular}{|r|rc|rc|}
\hline & \multicolumn{2}{|c|}{ NO PELL } & \multicolumn{2}{c|}{ PELL } \\
\hline & $\mathrm{N}$ & $12-18$ mo. retention & $\mathrm{N}$ & $12-18$ mo. retention \\
\hline blended & 40,310 & $78 \%$ & 15,728 & $79 \%$ \\
\hline fully onground & 42,705 & $76 \%$ & 18,283 & $74 \%$ \\
\hline fully online & 4,627 & $60 \%$ & 2,998 & $62 \%$ \\
\hline
\end{tabular}

Table 8 shows retention percentages for students who did and did not receive Pell grants. Proportionally fewer university students than community college students received Pell grants in this study. Moreover, the retention rates are quite similar for those receiving or not receiving Pell grants, indicating that financial support may not be as important for retention among this group as it is with community college students. The overall patterns of retention percentages by delivery mode, however, were much the same as those for four-year college students in general, which suggests that Pell status did not differentially affect delivery mode differences.

Table 9: Four-year college student retention by gender

\begin{tabular}{|r|rc|rc|}
\hline & \multicolumn{2}{|c|}{ FEMALE } & \multicolumn{2}{c|}{ MALE } \\
\hline & $\mathrm{N}$ & $12-18$ mo. retention & $\mathrm{N}$ & $12-18$ mo. retention \\
\hline blended & 33,043 & $79 \%$ & 21,820 & $78 \%$ \\
\hline fully onground & 26,569 & $77 \%$ & 26,975 & $75 \%$ \\
\hline fully online & 4,781 & $60 \%$ & 2,027 & $59 \%$ \\
\hline
\end{tabular}


Table 9 shows the average retention percentages for female and male PAR students enrolled in four-year colleges broken out by delivery mode. It is interesting to note that the majority of men enrolled in four-year universities chose to take all their courses onground, whereas only $41 \%$ of the women in this population did so. Indeed, $7 \%$ of the four-year university women but only $4 \%$ of the men took all their courses online. This finding deserves further explanation.

As with the community college data, Table 9 shows that more women were enrolled than men and that they were slightly more likely to be retained, but the gender differences were much smaller for the university populations. The patterns of retention by delivery mode, however, remained the same for this breakout, indicating that gender did not differentially affect differences related to delivery modes.

Table 10: Four-year college student retention by age

\begin{tabular}{|r|c|c|c|c|}
\hline & \multicolumn{2}{|c|}{ YOUNGER (<26 years) } & \multicolumn{2}{c|}{ OLDER (26+ years) } \\
\hline & $\mathrm{N}$ & $12-18$ mo. retention & $\mathrm{N}$ & $12-18$ mo. retention \\
\hline blended & 14,551 & $78 \%$ & 2.862 & $75 \%$ \\
\hline fully onground & 31.854 & $75 \%$ & 2,402 & $70 \%$ \\
\hline fully online & 1,539 & $57 \%$ & 3,605 & $57 \%$ \\
\hline
\end{tabular}

Table 10 presents delivery mode breakouts compared between students who were 25 years of age or younger and students who were 26 years of age or older. Due to technical problems, the data used in the comparison had to be reduced by one institution, the largest primarily onground university and one with a majority of students blending their classes. Thus it must be kept in mind that these age comparisons differ from the other comparisons in this category in that the percentage of students blending courses in the data used for the comparison was 15 percentage points fewer than that used for the other analyses in this category.

Nonetheless, the percentage of fully online students in the older group was ten times greater than the percentage of fully online students in the younger group, while the percentage of younger students taking all their courses onground was nearly three times as great as those taken by older students. This dichotomy suggests that the access to higher education provided by online courses has importance for older students. However, the patterns of retention in this category were quite similar across age groupings, indicating that delivery mode did not differentially affect students of differing ages.

The results of these comparisons, then, suggest that delivery mode did not differentially affect students receiving vs. students not receiving Pell grants, female vs. male students, or younger vs. older students at the primarily onground four-year universities involved in this study. Potential differential effects of taking classes online, however, should be explored for other student populations, especially at-risk groups such as ethnic and racial minorities, or students who are the first in their families to attend college.

\section{Primarily Online Institutions}

Finally, analyses similar to those undertaken for primarily onground community colleges and four-year universities were undertaken for four institutions whose primary focus was on online courses. These institutions were especially diverse. They included a public community college in the southwest, a public four-year university on the east coast, and two for-profit universities. The "primarily online" category was so constituted, in contrast to the more common practice of creating a 
unique "for-profit" category, because within the PAR community, we have found that institutions focusing on online programs are more similar to each other and less similar to primarily onground institutions.

The institutions representing the primarily online group had onground campuses located throughout the United States, and in one case, overseas. They had the largest number of students enrolled during the period studied, ranging from over 68,000 to almost 100,000. Percentages of students receiving Pell grants at these institutions ranged widely (20\% to $80 \%$ ) and females outnumbered males at all but one of the primarily online institutions studied.

The vast majority of the students in the primarily online category were, unsurprisingly, fully online students. However, three of the four institutions in this group had a sufficient number of fully onground students to make it possible to investigate all three levels of delivery mode, making it possible to ask similar questions of this category of institutions. Part of the rationale for doing so was to explore whether primarily online institutions might have better retention rates for students taking online courses than primarily onground institutions. They did not. The patterns of retention across delivery modes, however, were somewhat different.

\section{Are there any differences in completion and/or retention rates associated with differing delivery modes at primarily online institutions?}

Table 11: Retention and credit ratios for students enrolled in primarily online institutions by delivery mode.

\begin{tabular}{|r|c|c|c|c|}
\hline & $\mathrm{N}$ & $\begin{array}{c}12-18 \mathrm{mo} . \\
\text { retention }\end{array}$ & credit ratio & $\begin{array}{c}\text { credits } \\
\text { attempted }\end{array}$ \\
\hline blended & 29,577 & $45 \%$ & 0.66 & 15.7 \\
\hline fully onground & 48,067 & $29 \%$ & 0.76 & 13.4 \\
\hline fully online & 252,522 & $31 \%$ & 0.52 & 9.7 \\
\hline
\end{tabular}

Table 11 shows the 12-18-month retention rates, credit ratios and credits attempted for students enrolled in primarily online institutions broken out by delivery mode. The retention rates are clearly lower for this category of institutions except among students taking all their courses online, for whom the retention rates are similar to those of community college students taking all their courses online. Table 9 also shows that students taking only online courses in primarily online institutions were slightly more likely to be retained than students taking only onground courses, a deviation from the patterns across delivery modes for primarily onground institutions. However, as with primarily onground institutions, students taking some courses online and some courses onground were retained at higher rates than students taking only onground or only online courses.

After controlling for possible confounding variables in a logistic regression model, results revealed moderate differences between students taking a blend of courses and students taking their courses exclusively online or exclusively onground (Table 12). Students in the blended group at primarily online institutions had between 1.2 and 1.8 times greater odds of being retained than students taking all their courses onground (although there were no significant differences at one such institution and not enough only onground students to make a comparison at another). Students in the blended group also had between 1.2 and 1.4 times greater odds of being retained than students taking all their courses online (although there were no significant differences between the groups at one institution). Students taking only onground courses had greater odds of retention than students taking only online courses at one institution and slightly lower odds of retention than students taking only online courses at another. 
Table 12: Odds ratios comparing the odds of retention to a second year of students in differing delivery mode groups

\begin{tabular}{|r|c|c|c|c|}
\hline & Institution & Institution & Institution & Institution \\
& 1 & 2 & 3 & 4 \\
\hline blended vs fully onground & $\mathrm{na}^{*}$ & 1.8 & 1.2 & 1.0 \\
\hline blended vs fully online & 1.3 & 1.4 & 1.2 & 1.0 \\
\hline fully onground vs fully online & $\mathrm{na}^{*}$ & .77 & 1.0 & 1.2 \\
\hline
\end{tabular}

*not enough fully onground students at Institution 1 for valid comparison

The results suggest that among the PAR primarily online institutions, students taking a blend of courses were more likely to be retained, but there is little evidence that there are significant differences in retention odds between fully onground and fully online students after accounting for extraneous variables. The results suggest that at primarily online institutions, students taking some courses online and some courses onground are more likely to be retained than students taking all their courses either online or onground. While it should be noted that only a small percentage (9\%) of these students blended their courses, the finding clearly deserves further investigation.

The average credit ratio for students blending courses at primarily online institutions (.66) was similar to that for students blending courses at community colleges, while it was lower than that for students taking only online courses at community colleges, and for all delivery categories at fouryear universities. The average credit ratio for students at primarily online institutions taking only onground courses was quite high (.76) which is interesting, but may reflect the particular nature of onground courses at online institutions. It may be that the onground courses offered include a significant number of orientation courses or success type courses. Clearly, however, the result should be further investigated.

The average credits attempted by students enrolled in primarily online institutions were a good bit lower across all categories than average credits attempted at either community colleges or fouryear universities. This finding suggests that students enrolling at primarily online institutions may do so because of access issues, most likely time constraints. Time constraints might explain not only lower credits attempted but also lower retention and credit ratios as well. This notion too clearly deserves further investigation.

\section{Does delivery mode differentially affect particular groups of college students at primarily online schools?}

As with the primarily onground institutions, further analyses were made to see whether Pell status, gender or age differentially interacted with the ways in which delivery mode affected students at primarily online PAR institutions. Indications were that they did not, except in one somewhat questionable instance.

Table 13: Student retention at primarily online institutions by Pell status

\begin{tabular}{|c|c|c|c|c|}
\hline & \multicolumn{2}{|c|}{ NO PELL } & \multicolumn{2}{|c|}{ PELL } \\
\hline & $\mathrm{N}$ & 12-18 mo. retention & $\mathrm{N}$ & $12-18$ mo. retention \\
\hline blended & 20,933 & $40 \%$ & 25,344 & $51 \%$ \\
\hline fully onground & 33,453 & $25 \%$ & 14,614 & $61 \%$ \\
\hline fully online & 64,880 & $25 \%$ & 141,102 & $39 \%$ \\
\hline
\end{tabular}


Table 13 compares students who received Pell grants with students who did not receive them for all three delivery modes. A higher percentage of students in the primarily online segment received Pell grants when compared to the primarily onground institutions, and, as with community college students, Pell recipients were retained at higher rates, indicating perhaps a greater need for financial assistance. With one exception, the patterns of retention for each delivery mode resembled that of overall retention by delivery mode for the primarily onground category. The one exception was a higher rate of retention for Pell recipients taking only onground classes than for students in any other delivery mode by Pell status category. Such students only represent about $4 \%$ of the total population and the difference seems to be driven by a single institution with a tiny onground population (and so primarily an artifact of the way averages were calculated). Thus, while it is clearly of interest to that institution, it probably does not represent a general trend.

Table 14: Student retention at primarily online institutions by gender

\begin{tabular}{|r|rc|rc|}
\hline & \multicolumn{2}{|c|}{ FEMALE } & \multicolumn{2}{c|}{ MALE } \\
\hline & $\mathrm{N}$ & $12-18$ mo. retention & $\mathrm{N}$ & $12-18$ mo. retention \\
\hline blended & 26,939 & $49 \%$ & 18,744 & $43 \%$ \\
\hline fully onground & 21,488 & $30 \%$ & 25,109 & $26 \%$ \\
\hline fully online & 163,741 & $34 \%$ & 93,501 & $28 \%$ \\
\hline
\end{tabular}

Table 14 shows retention broken out by gender for students in all three delivery mode groupings - blended, fully onground, and fully online-at primarily online institutions. The data show that there were considerably more women than men enrolled at such institutions and that women were retained at slightly higher rates than men. The patterns of retention by delivery mode, however, mirror those for this category of institutions overall.

Table 15: Primaily online student retention by age

\begin{tabular}{|r|c|c|c|c|}
\hline & \multicolumn{2}{|c|}{ YOUNGER (<26 years) } & \multicolumn{2}{c|}{ OLDER (26+ years) } \\
\hline & $\mathrm{N}$ & $12-18$ mo. retention & $\mathrm{N}$ & $12-18$ mo. retention \\
\hline blended & 20,782 & $41 \%$ & 25.487 & $47 \%$ \\
\hline fully onground & 48,167 & $28 \%$ & 74.158 & $27 \%$ \\
\hline fully online & 95,778 & $27 \%$ & 156.683 & $34 \%$ \\
\hline
\end{tabular}

Table 15 explores possible differential effects of age on the retention of students in differing delivery mode categories. There were many more older students in this category than younger, which is quite different from students in primarily onground institutions. Moreover, older students taking only online courses in this category were retained at a considerably higher rate than younger ones taking only online courses, another indication of the importance of this delivery mode for older students.

The results of the comparisons in this category suggest that delivery mode did not differentially affect students receiving vs. students not receiving Pell grants or male students vs. female students at the primarily online institutions involved in this study. However, age differences did seem to do so. Potential differential effects of taking classes online should be explored for other student populations, especially at-risk groups such as ethnic and racial minorities, or students who are the first in their families to attend college. 


\section{Discussion}

To a large extent, online learning was developed to provide access to higher education for underserved populations, and access for underserved populations remains a measure of quality in online programs (Online Learning Consortium, 2015). Some of the findings in this study provide evidence that online courses and programs continue to offer such access.

Table 16: Enrollments by institution type and delivery mode

\begin{tabular}{|r|c|c|c|c|}
\hline & onground CC & 4-year onground & primarily online & totals \\
\hline blended & 91,622 & 54,867 & 29,577 & 176,066 \\
\hline fully onground & 112,269 & 53,544 & 48,067 & 213,880 \\
\hline fully online & 9,165 & 7,625 & 252,522 & 269,312 \\
\hline totals & 213,056 & 116,036 & 330,166 & 659,258 \\
\hline
\end{tabular}

For example, there were many more students enrolled in the primarily online institutions investigated in this study (Table 16), than in either the community colleges (more than 1.5 times as many) or the four-year universities (2.8 times as many). Although the institutions in this study are not a representative sample of institutions across the nation, the raw number of students in the primarily online segment demonstrates the current demand for online courses and programs. It is also important to note that none of these institutions were primarily online 20 years ago, that they have all grown phenomenally as a result of online offerings, and that such growth has only been possible because of the scalability of online courses. One could also argue that these institutions have grown because there is a demand for the access online courses provide to students with busy lives.

Indeed, a higher percentage of older students were enrolled at primarily online institutions (Figure 1). There were more than 11/2 times as many older students as younger ones at primarily online institutions, while there were nearly three times as many younger students at primarily onground community colleges. It thus seems that online courses offer particular access to higher education for older students in a way similar to the access given to younger students by community colleges.

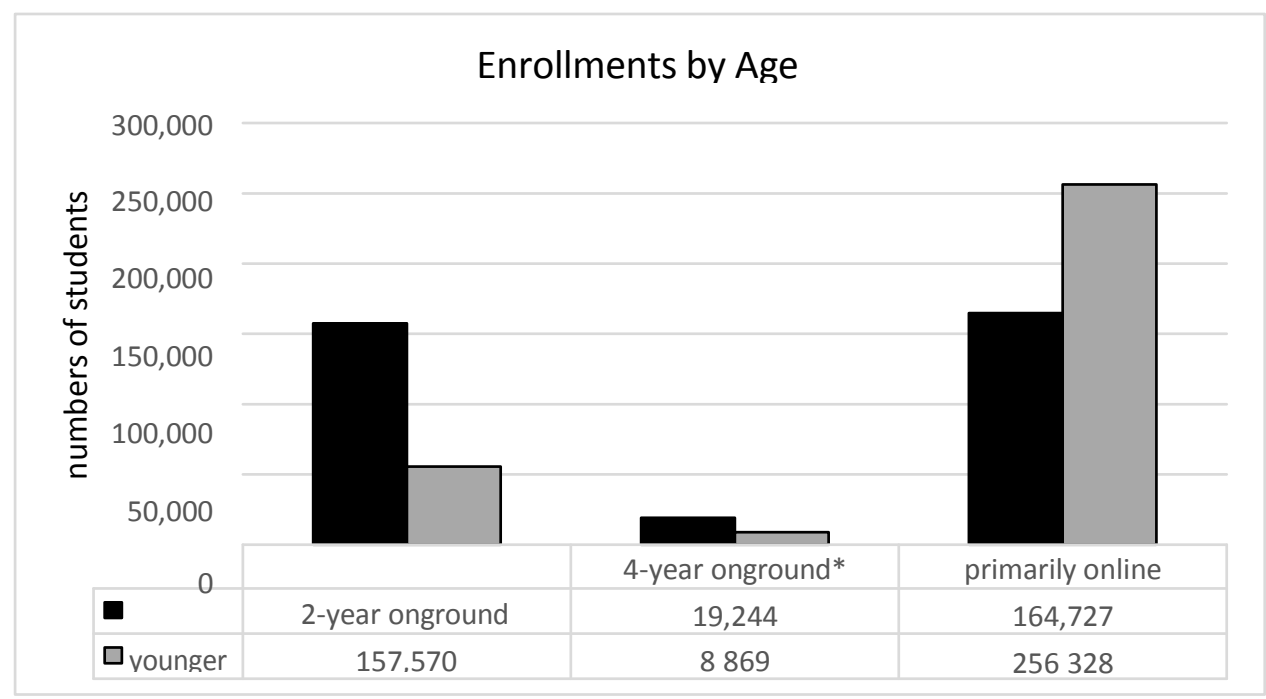

*4-year onground institutions in this comparison include 4/5 of the schools in other comparisons

Figure 1: A comparison of enrollments by age across differing categories of institutions 
In addition, considerably more than half of all students at primarily online institutions received Pell grants, whereas at primarily onground institutions more than half of all students did not receive Pell grants (Figure 2).

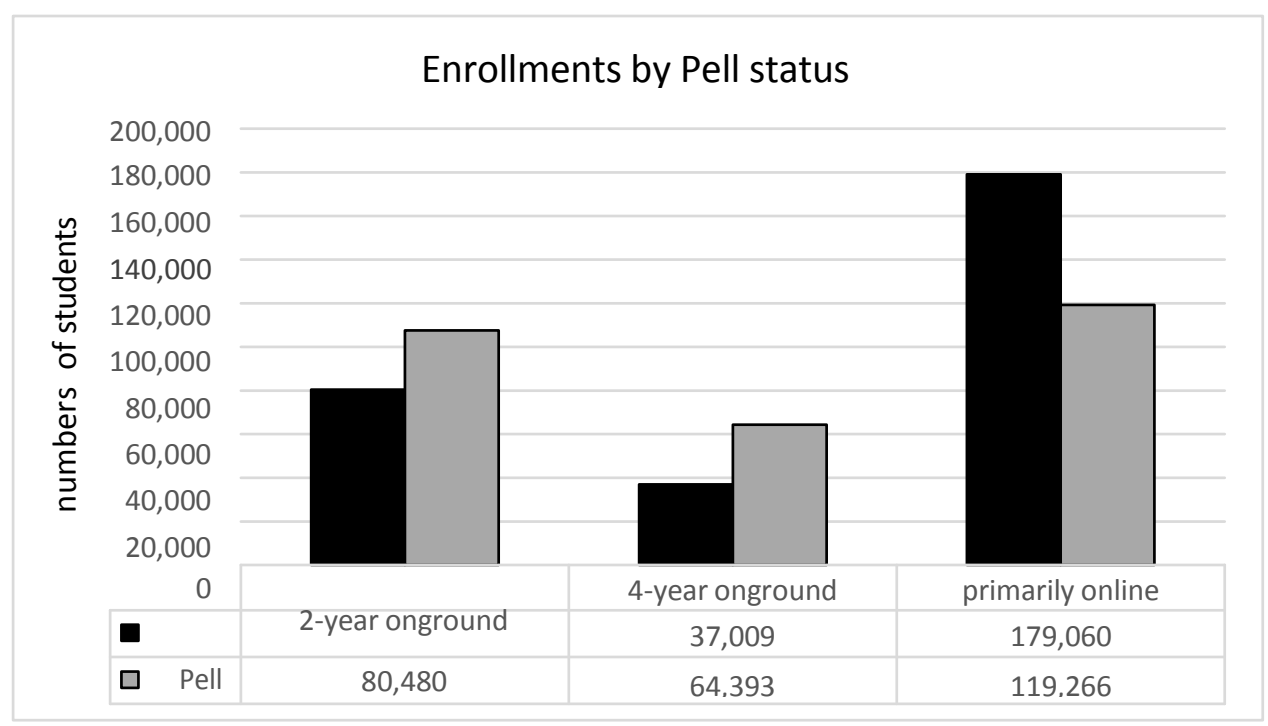

Figure 2: A comparison of enrollments by Pell status across differing categories of institutions The growing number of students who informally blend online and onground courses

(Bloemer \& Swan, 2014) also suggests the importance of online offerings for those students we continue to call "alternative." Almost half the students at primarily onground community colleges and over half the students at primarily onground universities took at least some courses online in their first eight months. In fact, "traditional" students, who attend college full time right after high school and live on campus, only amount to $15 \%$ of those attending college in this country, while alternative students -- "working parents, veterans and military personnel, caregivers and others" -- make up 85\% of that population (UPCEA, 2014).

Another piece of evidence which points to online courses being a way for nontraditional students to access higher education is a comparison of the number of courses students are taking at different categories of institutions in differing delivery modes. While credit ratios (Figure 3) are not all that different across institutional types, the numbers of credits attempted really are quite different (Figure 4). Across institutional types, the average number of credits attempted for both students taking only onground courses and students blending online and onground courses was 19.8. The average number of credits attempted for students taking only online courses was 11.5. On the other hand, it is interesting how remarkably similar the patterns of credits attempted look for community college students and students attending primarily online institutions in this study. One could argue that these findings again point to the notion that community colleges have been the traditional way for nontraditional students to access higher education, and that primarily online schools are emerging as another path to higher education for nontraditional students. At the very least, both are open access institutions. 
Figure 3: A comparison of credit ratios by delivery modes across differing categories of institutions

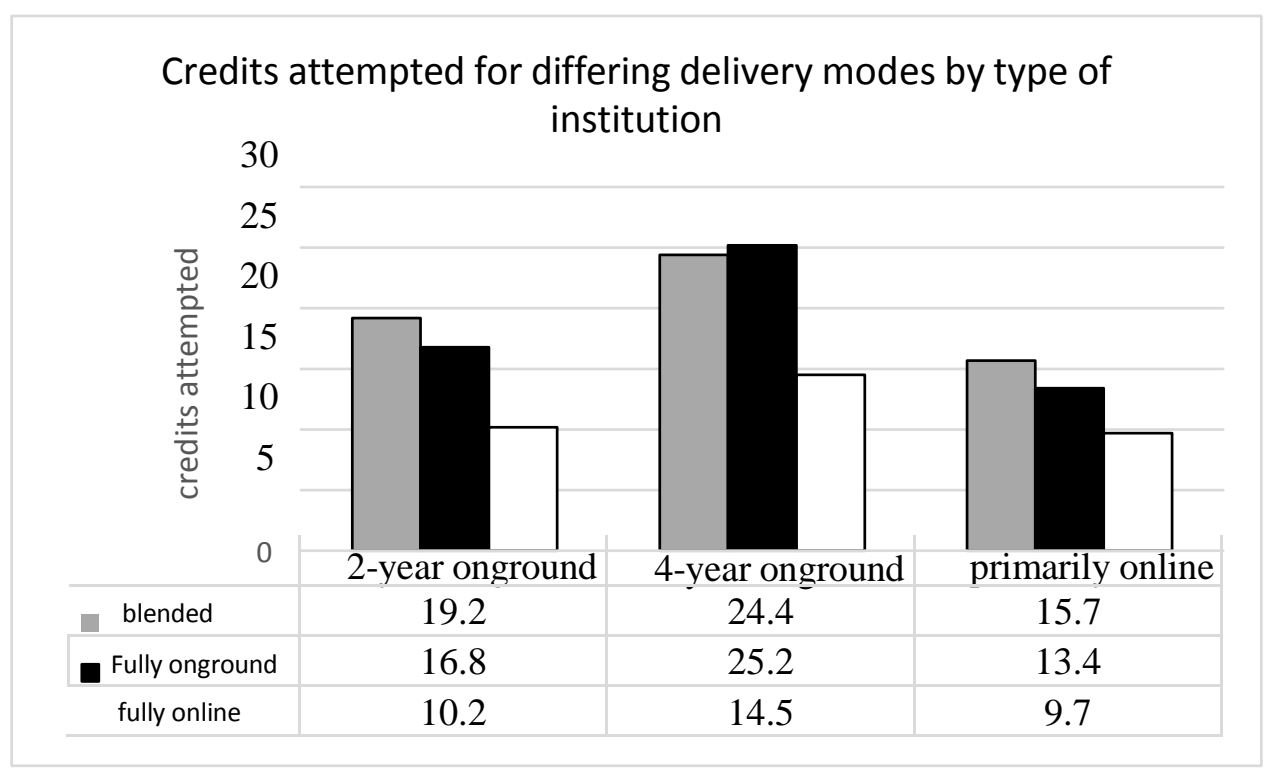

Figure 4: A comparison of credit attempted by delivery modes across differing categories of institutions

If a primary intention of online learning is to provide educational opportunities for students who are not able to attend courses in person due to time and/or location restraints, it is important to keep that intention in mind. The results of this study suggest that when other student characteristics are accounted for, participation in online and onground courses did not have a large impact on odds of retention when compared to participation in only onground courses. In fact, in most instances students who blended online and onground courses were more likely to be retained than students taking only onground courses.

Percent of students retained in differing delivery modes by type of institution

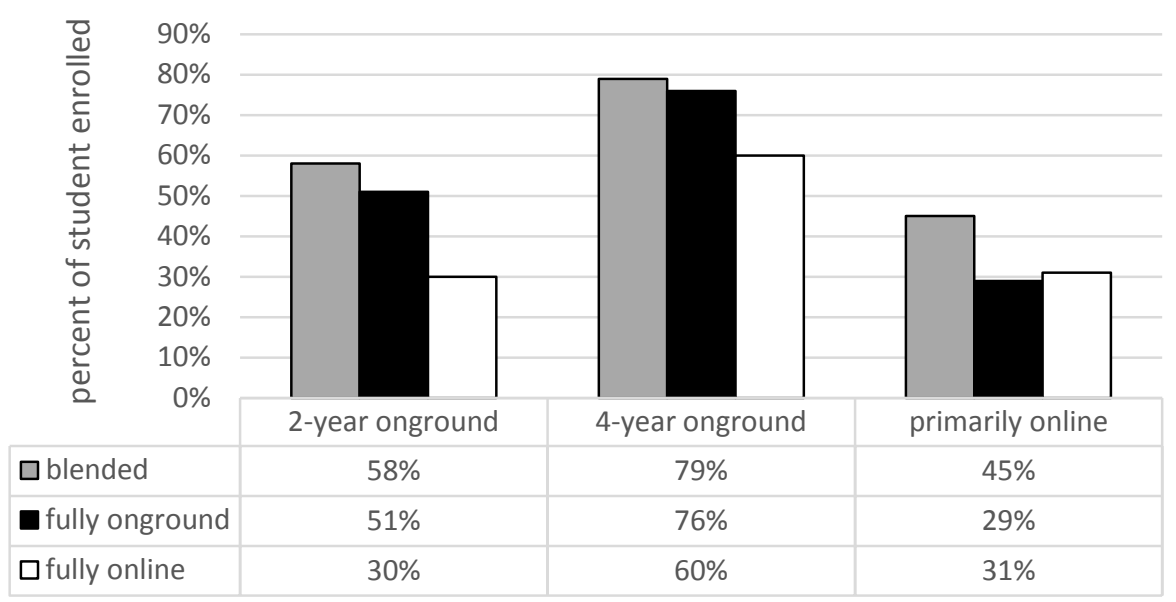

Figure 5: Comparisons of retention rates by delivery modes and institution types 
This is an important finding in that it suggests that the widely circulated notion that taking any online classes hurts community college students in particular, and other post-secondary students by implication, is not necessarily the case. For community college students in this study, taking some online classes led to slightly higher retention and progression rates than taking only onground classes (Figure 5). Moreover, the same was true of students enrolled in primarily onground four-year universities and primarily online institutions, and across students differentiated by Pell status and gender.

Why blending courses is associated with higher retention rates surely deserves further investigation. Perhaps blending courses gives students greater flexibility than taking courses only onground, and so makes it easier for them to stay enrolled when things in their lives might interfere with onground schedules. On the other hand, perhaps blending courses gives students a feeling of attachment to a real place, a brick and mortar institution, and that is more binding than the attachment to a virtual institution associated with taking courses only online. Understanding what makes blending courses a more effective delivery mode might help us better support all students.

Findings from this study also indicated that taking all courses online was at worst associated with moderately lower odds of retention (the largest odds ratio being 1.8 when compared against fully onground students) and at best associated with the same odds of retention as students taking all courses onground or students blending their courses online. It is important to note in this regard, that, if online courses are the only way some students can access higher education, deployed military or single mothers for example, then they are really not bad at all.

Perhaps finding ways of adding some onground experiences to primarily online programs would further reduce any differences in student retention.

Indeed, differences observed in retention rates between the three different delivery modes were largely explained by extraneous factors, rather than the delivery mode itself. One such extraneous factor was total credits attempted, which may be associated with the available time a student has to participate in courses. Lower credit attempts were negatively associated with retention at the participating institutions, and fully online students also attempted fewer credits than the students in the blended and fully onground groups at the primarily onground institutions. In this way, it appears online courses likely serve otherwise at risk students, who may among other things have time constraints that make attending onground courses difficult. Further points of study may be to investigate what factors place online students at risk that may not be risk factors for fully onground students, and to investigate whether specific segments of the student population are better suited for online or onground coursework.

Another area for investigation is institutional differences in the way students experience online course-taking and the degree to which certain institutional policies and practices related to the timing of online courses impact course completion and retention. Even within an institutional grouping with consistent trends, such as with traditional community colleges, odds ratios related to retention vary. Within our PAR member institutions, policies related to timing of online course-taking also differ. For example, at one of the traditional four-year schools, students are not allowed to enroll in online courses until their second semester.

Both primarily online and traditional onground schools often use college readiness instruments that measure technology aptitude to determine if a skills gap needs to be filled before embarking on online course-taking. Most institutions that offer online courses have online orientations - some mandatory, some optional- to help students learn more about the institution's particular approach to online courses prior to taking a credit bearing course. All these factors

and other interventions designed to enhance online success merit additional research to determine their contribution and influence on course outcomes and retention. 


\section{Limitations}

Data for this study was limited to the fourteen PAR Framework institutional partners who agreed to participate, and as such represents a sample of convenience rather than a stratified national or regional sample of post-secondary institutions. Findings, therefore, may or may not be representative of undergraduate students nationally. The participating institutions, however, were quite diverse both in student bodies and institutional focus, and they were located throughout the United States. Although an extensive number of potential confounding factors were considered and controlled for, it is also possible that unmeasured variables could have influenced the results as well. For instance, information on whether or not a student has a full time job and/or is providing for a family could impact the results as such students would likely have less time to spend on coursework and may be more inclined to take courses online as a result. It could be that some of the negative relationships observed between online coursetaking and retention may actually reflect that many online students have less time to dedicate to their studies, and more information on a student's work and family life could help control for those potential differences. This research is also limited to retention to a second year. A second and more extensive study could include retention beyond the first year and the examination of graduation rates among students in the three different delivery modes.

\section{Conclusions}

The research reported in this paper found that, contrary to what has been widely reported in the press taking some online courses did not result in lower retention or course completion rates for students enrolled in primarily onground community colleges participating in the PAR Framework. Moreover, although retention rates were lower for such students taking only online courses than for similar students taking only onground or blending their courses, the odds ratios for these differences were small (Chen, Cohen, \& Chen, 2010).

One important explanation for differences between these finding and other reports (Hart, Friedman, \& Hill, 2015; Jaggers \& Xu, 2010; Johnson \& Cuellar Majia, 2014; Xu \& Jaggers, 2011) is the way the data was grouped. In previous reports, students who took some online courses were grouped with students who took only online courses as "ever online". In the current study, these groups were separated with illuminating results - students who took some (but not all) courses generally were retained at higher rates than students who took all their courses onground; while students who took all their courses online had lower rates of retention. The findings suggest that taking some online courses is definitely not harmful and indeed may be beneficial. They perhaps provide some explanation for Shea and Bidjerano's (2014) findings associating taking some online classes with more likelihood of receiving a credential. The findings and the methodology surely deserve further investigation.

Essentially no differences in retention between delivery mode groups were found for students enrolled in primarily onground four-year universities participating in the PAR Framework, while at participating primarily online institutions, students blending their courses had slightly better odds of being retained than students taking exclusively onground or exclusively online courses. No differences between the latter groups were found at these institutions.

This study extends explorations of retention and the taking of online classes to the four-year and primarily online populations and finds no significant problems associated with taking online courses. The latter grouping, "primarily online," is another categorization unique to this study which may be significant. The study found that primarily online institutions, whether they be community colleges, fouryear public institutions, or for-profit colleges, are more like each other than primarily onground institutions. In particular, they serve a much larger alternative, and probably "at-risk" population. This notion should be investigated further.

Moreover, patterns of retention were the same regardless of gender across institutional categories 
and almost the same regardless of Pell status (there was a greater difference between students with a Pell grant and students without one among fully online students at primarily onground community colleges, than observed in the other two delivery modes). Age did seem to be a factor differentially affecting delivery mode at primarily onground community colleges and primarily online institutions. Older community college students taking only online courses were retained at higher rates than younger students taking only online courses. Similarly, older students taking only online courses or taking some online and some onground courses at primarily online institutions were retained at higher rates than younger students in the same categories. No differential effects of delivery modes were found for any groupings (female vs. male, Pell vs. no Pell, or younger vs. older students) among students enrolled in primarily onground four-year universities in this study.

The results thus suggest that online courses may provide access to higher education for people who have not traditionally had such access. Future investigations should examine the taking of online classes among traditionally underrepresented populations. The results indeed indicate that taking online courses is not harmful for most students, and may in fact be beneficial when online courses are blended with onground courses. The issue clearly deserves further investigation.

\section{References}

Allen, I. E., \& Seaman, J. (February. 2015). Grade Level: Tracking Online Education in the United States. Babson Survey Research Group.

Bernard, R., Abrami, P., Borokhovski, E., Wade, C., Tamim, R., Surkes, M., et al. (2009). A metaanalysis of three types of interaction treatments in distance education. Review of Educational Research, 79(3), 1243-1289

Bloemer, W. \& Swan, K. (2014). Investigating informal blending at the University of Illinois Springfield. In A. G. Picciano, C. D. Dziuban, \& C. R. Graham (Eds), Blended Learning Research Perspectives, Volume 2. New York: Routledge, 52-70.

Chen, H., Cohen, P., \& Chen, S. (2010). How big is a big odds ratio? Interpreting the magnitudes of odds ratios in epidemiological studies. Communications in Statistics - Simulation and Computation, 39(4), 860-864.

Hart, C. M. D., Friedmann, E., \& Hill, M. (April, 2015). Online course-taking and student outcomes in California community colleges. Paper presented at the 2015 annual meeting of the American Educational Research Association, Chicago.

Jaggers, S. S., \& Xu, D. (September, 2010). Online learning in the Virginia Community College system. New York: Community College Research Center, Teachers College, Columbia University.

Johnson, H., Cuellar Mejia, M., \& Cook, K. (2015). Successful Online Courses in California's Community Colleges. San Francisco, CA: Public Policy Institute of California.

Means, B., Toyama, Y., Murphy, R., Bakia, M., \& Jones, K. (2009). Evaluation of evidence- based practices in online learning: A meta-analysis and review of online learning studies. U.S. Department of Education.

Moore, J. C., \& Fetzner, M. J. (2009). The road to retention: A closer look at institutions that achieve high course completion rates. Journal of Asynchronous Learning Networks, 13(3), 322.

Online Learning Consortium. (2015). Five pillars of quality online education. Retrieved from: http://onlinelearningconsortium.org/about/quality-framework-five-pillars/

Shea, P. \& Bidjerano, T. (2014). Does online learning impede degree completion? A national study of community college students. Computers \& Education, 75, 103-111 
UPCEA (University Professional and Continuing Education Association). (October, 2014).

Federal Policy Brief. Retrieved from: http://www.upcea.edu/Files/UPCEAPolicyBrief.pdf

$\mathrm{Xu}, \mathrm{D} .$, \& Jaggers, S. S. (March, 2011). Online and hybrid course enrollment and performance in Washington State community and technical colleges. New York: Community College Research Center, Teachers College, Columbia University 